Research article

\title{
CONCURRENT OCCURRENCE OF LOWER RESPIRATORY ASPERGILLOSIS AND PNEUMOCONIOSIS IN A TURKEY FLOCK
}

\author{
TIMURKAAN Necati ${ }^{1 *}$, EROKSUZ Hatice ${ }^{1}$, ONGOR Hasan ${ }^{2}$, CEVIK Aydin ${ }^{1}$, \\ KARABULUT Burak ${ }^{1}$, TORAMAN Zulal Asci ${ }^{3}$,EROKSUZ Yesari ${ }^{1}$, \\ INCILI Canan Akdeniz ${ }^{1}$
}

\begin{abstract}
${ }^{1}$ Department of Pathology, Faculty of Veterinary Medicine, University of Firat, Elazig, Turkey; ${ }^{2}$ Department of Microbiology, Faculty of Veterinary Medicine, University of Firat, Elazig, Turkey; ${ }^{3}$ Department of Microbiology, Faculty of Medicine, University of Firat, Elazig, Turkey
\end{abstract}

(Received 25 April, Accepted 31 October 2017)

This study describes a concurrent occurrence of lower respiratory aspergillosis and pneumoconiosis in a turkey flock. From one flock of 1000 turkeys, 4 clinically affected turkeys were examined pathologically and microbiologically. Clinically affected turkeys showed anorexia, lethargy, drooping of the wing, vomiting, dyspnea and open-beak breathing, or sudden dead. Gross lesions were observed in the air sacs and lungs which presented white to yellowish granulomas of varying size. Microscopic there was multifocal granulomatous airsacculitis and pneumonia. At the center of the granulomas, fungal hyphae were clearly highlighted in the lungs and air sacs by Gomori methenamie silver (GMS) staining. In the microbiological cultivation of the affected lungs and air sacs, Aspergillus fumigatus was isolated on Sabouraud dextrose agar. Furthermore, dark black dust accumulations were present in the cytoplasm of macrophages or interstitial tissue in the lungs and air sacs. There were also fibrosis and lymphohistiocytic cell infiltrations around the particles. Overall, this study could implicated that pneumoconiosis might be a predisposing factor in the development of respiratory aspergillosis in turkeys.

Keywords: Aspergillosis, pneumoconiosis, turkey, respiratory system, pathology.

\section{INTRODUCTION}

Aspergillosis is a fungal disease caused by a member of the fungal genus Aspergillus that affects avian species, mammals and humans [1-3]. The disease may cause substantial economic losses in the poultry industry, in particular turkey breeding [2]. Aspergillosis is mostly caused by Aspergillus fumigatus in birds, but Aspergillus flavus, Aspergillus niger, Aspergillus nidulans, and Aspergillus terreus have been isolated from domestic and wild birds [3]. Aspergillus fumigatus is a ubiquitous organism that is capable of living under extensive environmental stress. The growth of Aspergillus fumigatus

\footnotetext{
*Corresponding author: e-mail: ntimurkaan@firat.edu.tr
} 
on organic material results in the formation of numerous small conidia which can reach the lower respiratory system by inhalation $[1,2,4]$. An increase of fungal spores in the environment and the failure of the host defense system are the basis for the occurrence of aspergillosis [2,4]. Clinically, the disease usually occurs in acute form in young birds with high morbidity and mortality, while it is chronic and sporadic in older avian species [1-3]. Aspergillosis has been reported in poultry such as chicken, turkey, goose, ostrich, duck [2,5-8] and wild birds [1,3].

Pneumoconiosis is an interstitial lung disease caused by inhalation of dust particles usually over a long term exposure [9-11]. Pneumoconiosis is also called occupational lung disease or coal workers' pneumoconiosis, is more common in humans than animals, because people work in a high risk mineral associated industry [12-16]. However, reports of pneumoconiosis have been described in domestic and wild mammals [17-19]. Pneumoconiosis has been reported in avian species such as kiwi, rhea, ostrich, touraco, swan, owl, crane, duck, eagle, pheasant in San Diago Zoo and Dhaka Zoological Park, and in hens [9,10,20-22]. However, the disease has not been reported in turkey which is an important species in poultry industry.

In humans, it has been well-documented that there is a relationship between pneumoconiosis and occurrence of aspergillosis. Binder et al., [12] have suggested that dust accumulation in the lungs causing fibrosis may have a role in the appearance of pulmonary aspergillosis. Moreover, some other researchers detected concurrent pulmonary aspergillosis and pneumoconiosis in humans, and stated a similar hypothesis [14-16]. To our knowledge, there is no report on concurrent respiratory aspergillosis and pneumoconiosis in animals. So, this study describes the first study reporting the concurrent pulmonary and air sacs aspergillosis, and pneumoconiosis in turkeys.

\section{MATERIALS AND METHODS}

The material of this study consisted of 4 dead, 6 -month - old turkeys from a flock of 1000 birds. The birds were raised in free range farming. Feed and water were administrated by workers, not automatically. The mortality rate of this flock was approximately $25 \%$. Only 4 dead birds were referred to the Department of Pathology, Faculty of Veterinary Medicine, University of Firat, for necropsy. The affected turkeys exhibited anorexia, lethargy, drooping of the wing, vomiting, dyspnea and open beak breathing, or sudden dead. Necropsy was performed in only 4 dead birds, and collected tissue samples were fixed in 10\% neutral buffered formalin, routinely processed, paraffin embedded, sectioned at $5 \mu \mathrm{m}$ thickness, and stained with hematoxylin and eosin, Grocott's methenamine silver (GMS), Ziehl-Neelsen, Prussian blue methods for histopathological examination. Sections were examined by light microscopy with and without the use of polarizing filters. For microbiological examinations, tissue samples were collected from the lungs and air sacs with lesions, and were examined microscopically for the presence of hyphae by placing a small portion of the nodule in $20 \% \mathrm{KOH}$ solution on a microscope slide. Also, the samples were plated on both 
standard medium agar and Sabouraud dextrose agars with and without antibiotics. The samples plated on Sabouraud dextrose agar were incubated at both $37^{\circ} \mathrm{C}$ and $25^{\circ} \mathrm{C}$ separately and were checked for colony growth twice a week. Slide culture was made for microscopical assessment and species identification of colonies.

\section{RESULTS}

At necropsy, lungs and air sacs of four turkeys showed gross lesions, however more severe lesions were located in the air sacs. The thoracic and abdominal air sacs were covered with caseous material (Figure 1). There were white to yellowish granulomas ranging from $5 \mathrm{~mm}$ to $20 \mathrm{~mm}$ in the air sacs and the lungs. The nodules localized in the abdominal air sacs coalesced to form aggregate lesions in two cases. On the cut surfaces, the large nodules exhibited necrotic areas with a gray-greenish color. Serous atrophy of fat in the pericardium was seen in three turkeys. There were no remarkable gross lesions in the other organs. Histopathological evaluation revealed multifocal granulomas characterized by necrosis, inflammatory cell infiltrations of heterophils, macrophages, lymphocytes, giant cells and connective tissue proliferation in the lungs (Figure 2) and the air sacs. In some areas, the granulomas enlarged and compressed the adjacent air vesicles alveoli. In addition, edema, hemorrhage and trombosis around the necrotic areas were found. Ziehl-Neelsen staining was negative for acid-fast bacilli in the lungs and air sacs in any case. Fungal hyphae were clearly highlighted in the lungs and air sacs by GMS stain (Figure 3). In some sections, hyphae formed conidiophores and spores. Although there was no colony development on standard medium agar,

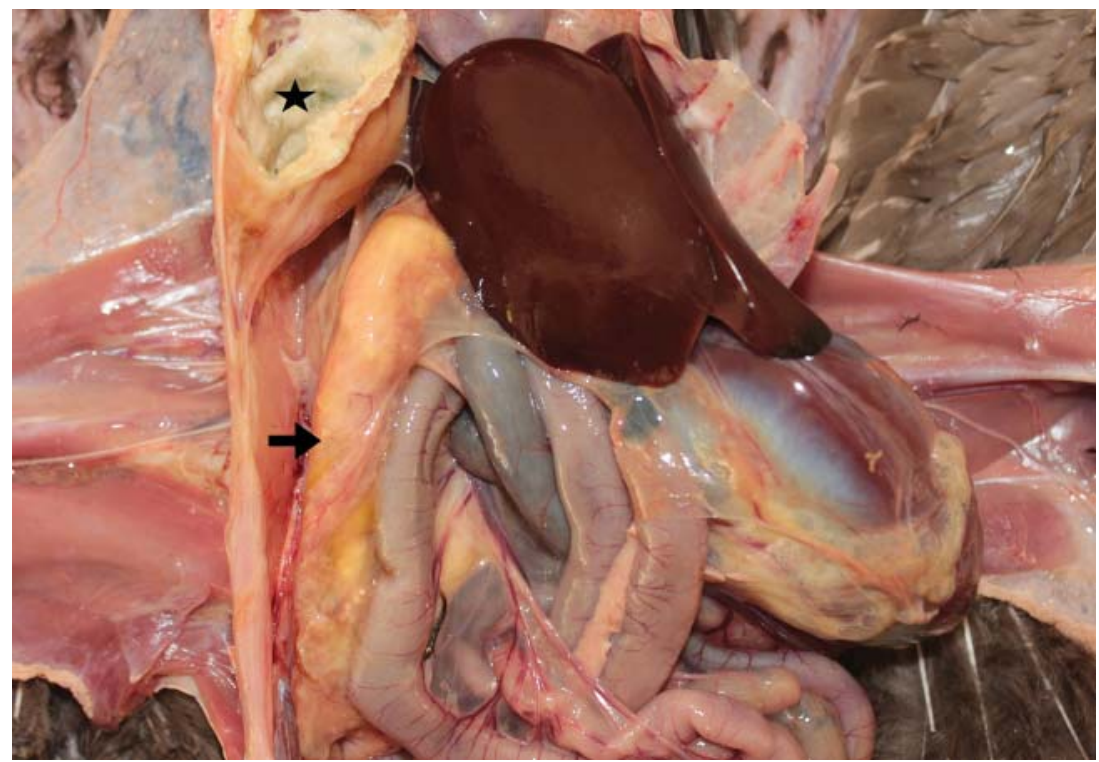

Figure 1. Necropsy image demonstrating enlarged thoracic (star) and abdominal air sacs (arrow) with caseous exudate in a turkey. 
growth was observed on Sabouraud dextrose agar at $37^{\circ} \mathrm{C}$ and $25^{\circ} \mathrm{C}$. The colonies were velvety, blue-green, the colony sides were white while the colony ground was canary yellow in color. In microscopical examination, smooth, short and greenish conidiophores, with a single row phylia and conidia with columnar composition over this were seen.

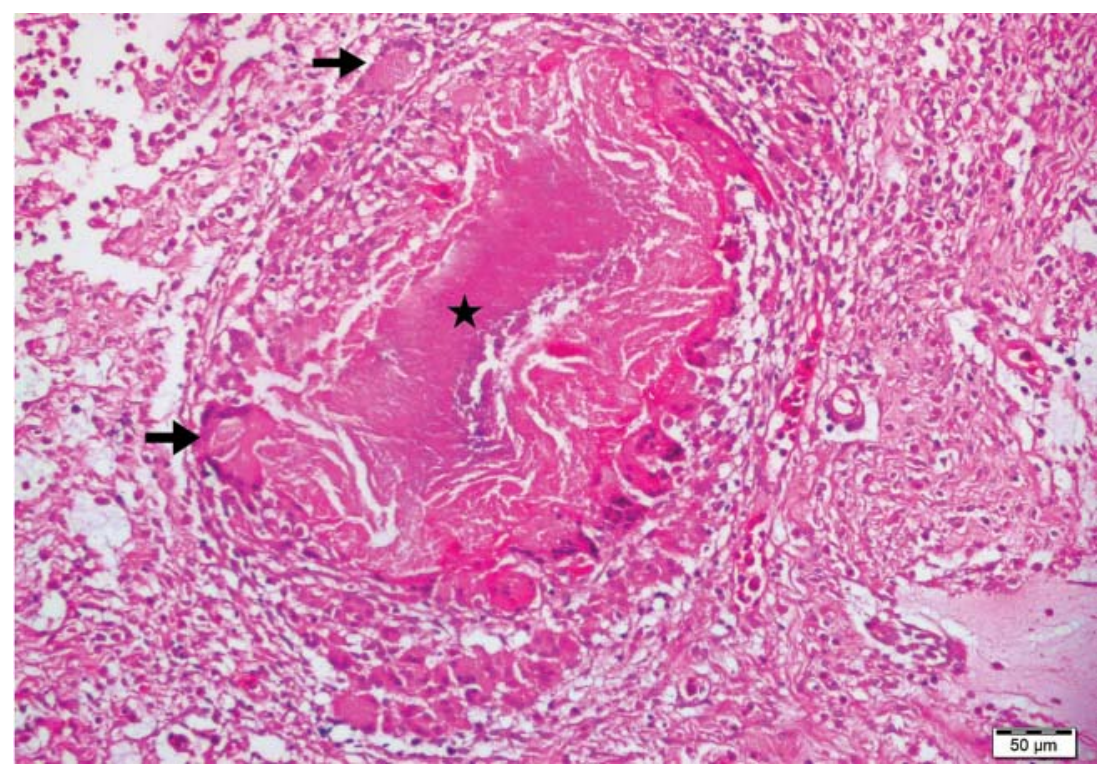

Figure 2. Photomicrograph, lung of a turkey. Granuloma showing a well demarked focus of necrosis (star) surrounded by mononuclear cell infiltration, giant cells (arrows) and connective tissue, HE stain.

By microscopical examination, black or dark brownish dust accumulation was also seen in many of the lungs and air sacs sections in these birds. In the lungs, particle aggregations showed multifocal distribution in the interstitial areas around the smooth muscle of the secondary and tertiary bronchioles, free or in the cytoplasm of the alveolar macrophages (Figure 4). In the air sacs, dust particles were localized in the submucosal connective tissue (Figure 5). In addition, there were mononuclear cells infiltration and connective tissue proliferation around the particles in the lungs and air sacs. The dust particles showed no staining with the Prussian blue staining method, but there was a birefringent appearance upon exposure to polarized light. 


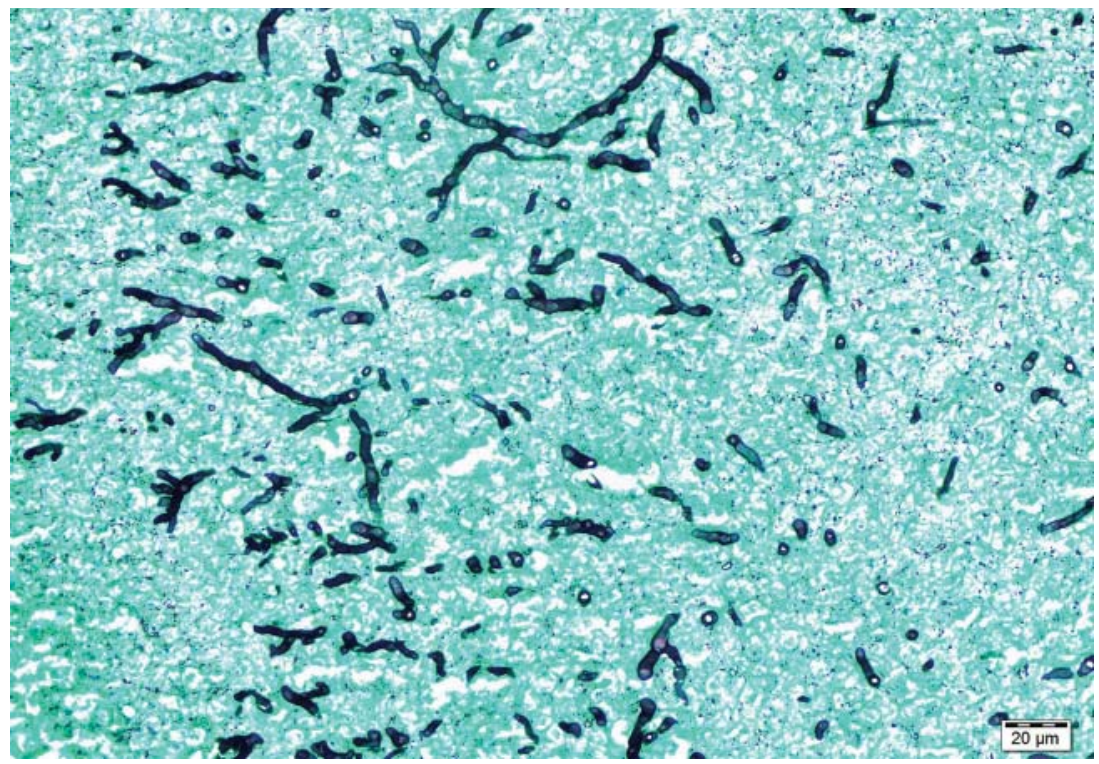

Figure 3. Photomicrograph, air sac of a turkey. Numerous fungal hyphae stained by GMS stain

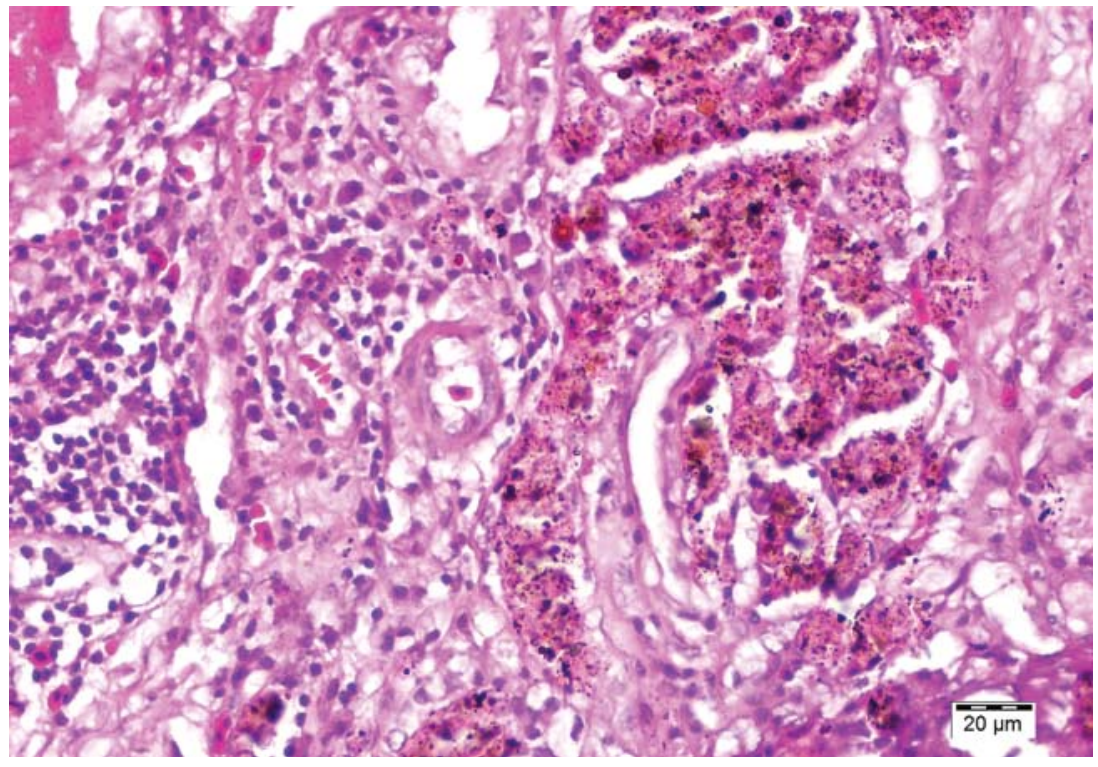

Figure 4. Photomicrograph of the lung of a turkey showing peribronchial black or dark brownish dust particles, free or within macrophages, HE stain. 


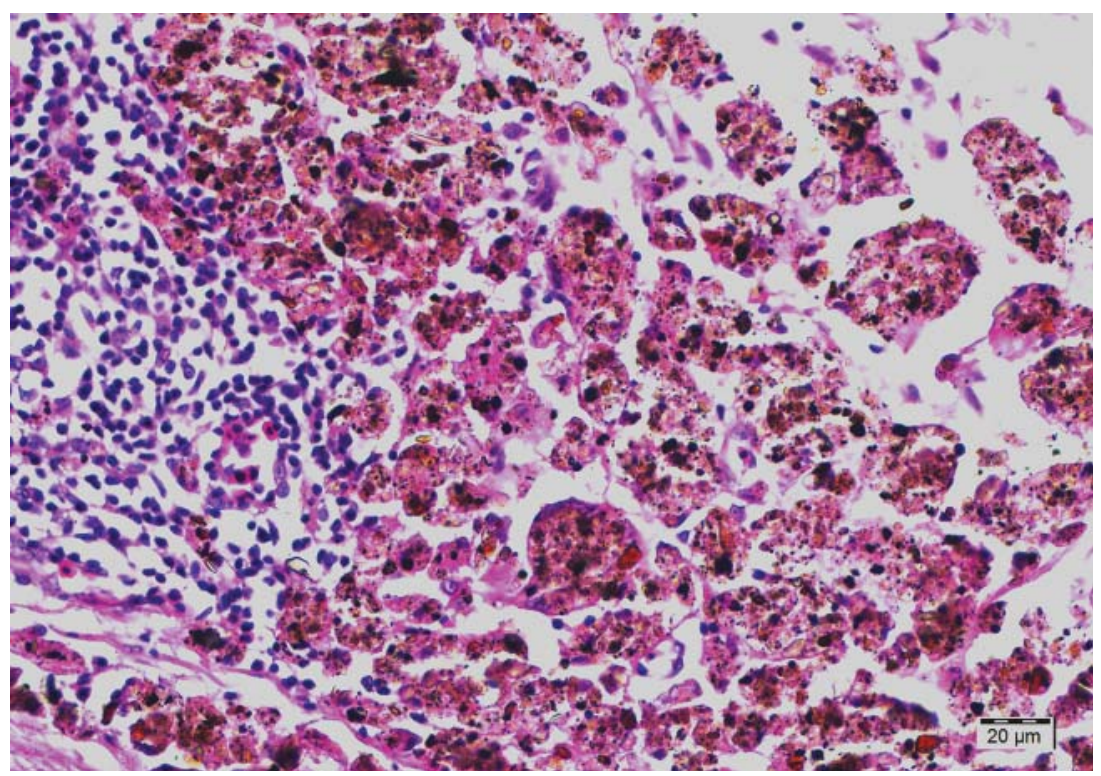

Figure 5. Photomicrograph of the thoracic air sac of a turkey showing black or dark brownish particles accumulation, free or within macrophages, and also mononuclear cells infiltration, HE stain

\section{DISCUSSION}

This study describes the concurrent pulmonary and air sacs aspergillosis, and pneumoconiosis in turkeys. Aspergillus fumigatus and Aspergillus flavus can cause respiratory disease. However, Aspergillus fumigatus has been mostly isolated during natural infections of poultry, and it causes a more severe respiratory disease than Aspergillus flavus infections [1,3]. In this study, Aspergillus fumigatus was isolated from the lungs and air sacs in turkeys. In this study, gross and histopathological findings of aspergillosis in the lungs and air sacs were similar to those reported previously for various poultry species $[2,3,6,8]$. It has been reported that the primary location of the lesions is the lower respiratory system even though other organs such as brain, heart, spleen, liver, kidney, skin may be involved [1,2]. In the present study, a gray to greenish color on the cross section of the larger nodules in the air sacs was seen, and it has been reported that this finding may be a sign of fungal sporulation $[2,4]$. The findings of aspergillosis are non-specific [1,3]. Therefore, the definitive diagnosis may be based on the isolation of $A$. fumigatus by culture and immunohistochemistry or by the detection of the organism using fungal histochemical stains such as periodic acidSchiff, GMS stainings during histological examination $[1-4,6]$. In the present study, numerous fungal hyphae were seen in the lungs and air sacs by GMS stain. Also, in 
microbiological cultivation, Aspergillus fumigatus was isolated and identified in the lung and air sacs.

Pneumoconiosis also known as dust lung is defined by pathological reactions that occur in the lungs exposed to air pollution in mammals $[11,13,20]$. The severity of the lesions depends on the type of inhaled dust and the intensity and period of exposure. Based on the histopathological changes in the lungs, pneumoconiosis has been subdivided as fibrotic or non-fibrotic $[13,18,19,23]$. Pneumoconiosis in birds has been reported as rare cases, but no information is available about dust accumulation in the air sacs of avian due to naturally exposure. In the present study, multifocal fibrosis and mononuclear cells infiltration around the mineral dusts were found in the lungs and air sacs of the turkeys. Experimental studies indicated that the deposition of inhaled particles depends on their size. Large particles are taken out in the upper respiratory tract, while small particles are accumulated throughout the lower respiratory system including air sacs [24,25]. In an experimental study, Anderson et al. [28] examined the effects of dust and ammonia on the respiratory system of turkeys and found no pathological changes in most cases. It has been reported that pneumoconiosis in birds occurs related to air pollution such as housing in dusty, enclosed locations, and dust from city traffic or nearby industrial facilities [9,20,22]. There was no industrial activity causing heavy air pollution in the region where this flock is located, and also the flock was far from the city traffic. Detailed anamnesis indicated that both the flock and the houses in the vicinity were heated by coal stoves. In addition, the flock had a diesel generator as an alternative electrical source, and according to the information given by the poultry owner, the generator was used because of frequent power failures. So, smoke and dust from the coal stoves and the generator appear to cause pneoumoconiosis in these birds. Definitive diagnosis of dust particles must be based on mineralogical analysis of air samples from animals' environment and lung tissue samples. In the present study, the elemental composition of the dust was not analyzed. It has been reported that silicosis, siderosis and anthracosis are the most common causes of pneumoconiosis in avian species [9,20-22]. Siderosis generally reacts positively with Prussian blue stain which was negative in the current study. The dust particles in the present study did not resemble silicosis, which is characterized by plate-like crystals $[10,14,21]$. From a histological point of view, the dust accumulation observed in the lung and air sacs in this study were consistent with the appearance of coal particle depositions previously reported [13,17-19].

Some researchers reported that there may be a relationship between pneumococciosis and some lung diseases such as pneumonia in sheep [18], cattle [19], camel [23], and neoplasia in dogs [17]. Furthermore, Binder et al. [12] reported that severe pulmonary aspergillosis was seen in humans who have underlying lung diseases such as pneumoconiosis, chronic obstructive lung disease, a history of tuberculosis and long-term steroid treatment. In another study [16], researchers tested $A$. fumigatus in sputum using polymerase chain reaction and reported that pneumococciosis may play an important role in the colonization of the respiratory tract with $A$. fumigatus. It has 
been reported that pneumoconiosis especially accompanied by pulmonary fibrosis, can disrupt the defense mechanism of the respiratory system, and thus, Aspergillus spp. may easily be colonized [14,15]. Impaired immunity and inhalation of a considerable amount of spores are important risk factors in aspergillosis $[1,3,14,15]$. In this study, with aspergillosis findings, dust particles were seen in both the lungs and the air sacs in the turkeys, and it was seen that the dust particles caused the inflammatory reaction in the lungs and air sacs. Moreover, lesions associated with aspergillosis in these birds were severe, and the mortality was about $25 \%$. The presence of dust accumulation in the lungs and air sacs suggests that pneumoconiosis may be a preparatory reason in the development of aspergillosis in these birds. Iossifova et al., [14] reported that aspergillosis was the most common fungal disease among humans with pneumoconiosis.

In conclusion, this paper is the first study reporting the concurrent lower respiratory aspergillosis and pneumococciosis in turkeys. The findings of the study also suggest that pneumoconiosis caused fibrosis in the lower respiratory system may be an underlying reason for the occurrence of fungal infection in avian species as reported in humans.

\section{Acknowledgement}

We thank Dr. Mehmet Calicioglu for valuable comments on the manuscript. We are grateful to the flock owner for his kind cooperation.

\section{Authors' contributions}

NT drafted the manuscriptand interpreted pathological findings. AC and BK participated in necropsies and histopathological analyses. CAI carried out histochemical staining. $\mathrm{HO}$ and ZAT made microbiological cultivation. HE helped to draft the manuscript. YE reviewed the study for scientific content. All authors read and approved the final manuscript.

\section{Declaration of conflicting interests}

The author(s) declared no potential conflicts of interest with respect to the research, authorship, and/or publication of this article.

\section{REFERENCES}

1. Kunkle RA: Fungal infection. In: Disease of Poultry.11th edition, Iowa State University Press, Ames, Iowa, 2003, 883-895.

2. Arne P, Thierry S, Wang D, Deville M, Le Loch G, Desoutter A, Femenia F, Nieguitsila A, Huang W, Chermette R, Guillot J: Aspergillus fumigatus in poultry. Int J Microbiol 2011, 2011: 1-14. 
3. Beernaert LA, Pasmans F, Waeyenberghe LV, Haesebrouck F, Martel A: Aspergillus infections in birds: a review. Avian Pathol 2010, 39: 325-331.

4. Guarner J, Brandt ME: Histopathologic diagnosis of fungal infections in the 21st century. Clin Microbiol Rev 2011, 24: 247-280.

5. Beytut E, Ozcan K, Erginsoy S: Immunohistochemical detection of fungal elements in the tissues of goslings with pulmonary and systemic aspergillosis. Acta Vet Hung 2004, 52: 71-84.

6. Beytut E: Immunohistochemical diagnosis of aspergillosis in adult turkeys. Turk J Vet Anim Sci 2007, 31: 99-104.

7. Cevik A, Eroksuz H: Aspergillosis in turkeys. Vet Bil Derg 2004, 20: 109-112.

8. Timurkaan N, Keskin O, Yilmaz F, Cimtay I: Aspergillosis outbreak in an ostrich flock. Med Weter 2005, 61: 765-766.

9. Ahasan SA, Chowdhury EH, Azam SU, Parvin R, Rahaman AZ, Bhuyan AR: Pulmonary anthracosis in Dhaka Zoo Collections -a public health forecasting for city Dwellers. J Threat Taxa 2010, 2: 1303-1308.

10. Brambilla C, Abraham J, Brambilla E, Benirchke K, Bloor C: Comparative pathology of silicat pneumoconiosis. Am J Pathol 1979, 96: 149-169.

11. Karkhanis VS, Joshi JM: Pneumoconioses. Indian J Chest Dis Allied Sci 2013, 55: 25-34.

12. Binder RE, Faling LJ, Pugatch RD, Mahasaen C, Snider G: Chronic necrotizing pulmonary aspergillosis: a discrete clinical entity. Medicine 1982, 61: 109-124.

13. Chong S, Lee KS, Chung MJ, Han J, Kwon OJ, Kim TS: Pneumoconiosis: Comparison of imaging and pathologic findings. Radiographics 2006, 26: 59-77.

14. Iossifova Y, Bailey R, Wood J, Kreiss K: Concurrent silicosis and pulmonary mycoseis at death. Emerg Infect Dis 2010, 16: 318-320.

15. Kato T, Usami I, Morita H, Goto M, Hosoda M, Nakamura A, Shima S: Chronic necrotizing pulmonary aspergillosis in pneumoconiosis* clinical and radiologic findings in 10 patients. Chest2002, 121: 118-127

16. Nomoto Y, Kuwano K, Hagımoto N: Aspergillus fumigatus Asp f I DNA is prevalent in sputum from patients with coalworkers' pneumoconiosis. Respiration 1997, 64: 291-295.

17. Bettini G, Morini M, Marconato L, Marcato PS, Zini E: Association between environmental dust exposure and lung cancer in dogs. Vet J 2010, 186: 364-369.

18. Beytut E: Anthracosis in the lungs and associated lymph nodes in sheep and its potential role in the occurrence of pneumonia. Small Rumin Res 2002, 46: 15-21.

19. Ozcan K, Beytut E: Pathological investigations on anthracosis in cattle. Vet Rec 2001, 149: 90-92.

20. Choudary CH, Mohan Rao MRK, Ali S: Anthracosis in zoo animals and birds. Indian Vet J 1986, 63: 869-870.

21. Reporto F, Borzacchiello R, Ungaro R, Galati P: Silicate pneumoconiosis in hens. J Comp Pathol 2000, 122: 249-254.

22. Smith BL, Poole WS, Martinovich D: Pneumoconiosis in the captive New Zealand Kiwi. Vet Pathol 1973, 10: 94-101.

23. Goodarzi M, Azizi S, Kouiaei MJ, Moshkelani S: Pathologic findings of anthraco-silicosis in the lungs of one humped camels (Camelus dromedarius) and its role in the occurrence of pneumonia. Kafkas Univ Vet Fak Derg 2014, 20: 171-176. 
24. Hayter RB, Besch EL: Airborne particle deposition in the respiratory tract of chickens. Poult Sci 1974, 53: 1507-1511.

25. Reese S, Dalamani G, Kaspers B: The avian lung-associated immune system: a review. Vet Res 2006, 37: 311-324.

26. Anderson DP, Wolfe RR, Cherms FL, Roper WE: Influence of dust and ammonia on the development of air sacs lesions in turkeys. Am J Vet Res 1968, 29: 1049-1058.

\section{ISTOVREMENA ASPERGILOZA I PNEUMOKONIOZA DONJIH PUTEVA RESPIRATORNOG SISTEMA U JATU ĆURAKA}

TIMURKAAN Necati, EROKSUZ Hatice, ONGOR Hasan,CEVIK Aydin, KARABULUT Burak, TORAMAN Zulal Asci,EROKSUZ Yesari, INCILI Canan Akdeniz

Studija opisuje istovremenu pojavu aspergiloze i pneumokonioze u donjim putevima respiratornog sistema ćuraka na farmi. Iz jata od ukupno 1000 ptica, ispitane su na prisustvo morfoloških promena i mikrobiološki, četiri ptice kod kojih su klinički uočene anoreksija, letargija, opuštena krila, povraćanje, dispneja i disanje sa otvorenim kljunovima kao i iznenadno uginuće. Patomorfološke promene su uočene u vazdušnim kesama i u parenhimu pluća i to u vidu belih i žućkastih granuloma, različite veličine. Histopatološki, uočene su multifokalne granulomatozne promene koje ukazuju na aerosakulitis i pneumoniju. U središnjem delu granuloma uz primenu Gomori metamin srebro (GMS) bojenja, bile su jasno uočljive hife gljivica u parenhimu pluća i $\mathrm{u}$ vazdušnim kesama. Mikrobiološkim ispitivanjem tj. izolacijom na hranljivim podlogama uzoraka iz tkiva pluća i vazdušnih kesa, izolovan je Aspergillus fumigatus. U citoplazmi makrofaga kao i u intersticijumu parenhima pluća i vazdušnih kesa, uočene su akumulacije koje su bile mutne, tamno sive do crne boje. Okolo partikula, nalazila se fibroza i infiltracija limfohistiocitnih ćelija. Pore ostlog ova studija bi mogla da ukaze da pnemokonioza može da bude predisponirajući faktor u razvoju respiratorne aspergiloze kod ćuraka. 